\title{
DISMANTLING DISASTER, DEATH, AND SURVIVAL IN PHILIPPINE ECOPOETRY
}

\author{
Rina Garcia Chua \\ University of Santo Tomas \\ rinagarciachua@gmail.com
}

\begin{abstract}
The Philippines, a country situated close to the equator and in the Pacific Ring of Fire, has been constantly hit by natural disasters such as typhoons, earthquakes, landslides, and more. With a good number of local poetry dealing with these natural disasters as themes, is it possible for ecopoetry to provide readers with clear ideas on how to survive these catastrophic events? The major objective of this study is to explore the role of literature in promoting survival through the exploration of death and disaster in poetry. To do this, the different versions of disaster in the poetry of Merlie Alunan and Abercio V. Rotor are analyzed using the concept of "dismantling." Dismantling involves surfacing the "scars of history" in poetry to create an ambience of disaster, which will link the dismantling of the (inside) feelings of the human being with the (outside) physical experience to clear a space for survival. Here, ecopoetry serves as a catalyst for sustainable thoughts which can be calls to action for preventing future disasters. Moreover, ecopoetry is also a "witness to history" wherein writing about disasters is acknowledged as an act of surviving, conquering trauma, and providing a personal perspective to historical survival accounts. Ecopoetry, then, is also demonstrated as a "time capsule" of certain tragedies - one that may be more accurate than memory can ever be.
\end{abstract}

\section{Keywords}

disaster studies, ecocriticism, poetry, sustainability, trauma

\section{About the Author}

Rina Garcia Chua completed her degree of Master of Arts in Language and Literature, major in Literature from the De La Salle University - Manila. Her manuscript was awarded a gold medal for Outstanding Thesis and chapters from it have been presented in international and national conferences. She also has been a fellow in several national writers' workshops and was accorded the International Membership Grant by the Association for the Study of Literature and the Environment (ASLE). Currently, she is editing an anthology of Philippine ecopoetry, "Sustaining the Archipelago," and is affiliated with the Literature Department of the University of Santo Tomas. 
Two hours past midnight on the seventeenth of December 2011, flood waters raged into the residential areas of Cagayan De Oro, Iligan, and Negros Oriental. As a result of Tropical Storm (TS) Sendong, these murky waters quickly overran the streets and houses, forcing residents to take refuge on their roofs and, in the dark, and to wait for rescue. The flash flood was exacerbated by the denuded forests in the mountains of Bukidnon - from both legal and illegal logging - leaving the water to freely flow from the mountaintops to the cities on its base. To make matters worse, hundreds of unshipped logs from the mountains were carried by the muddy water into the Cagayan de Oro River, where urban poor communities and government buildings surrounded the banks and its sandbars.

No one was prepared when this disaster struck: people were either fast asleep or preparing for their upcoming Christmas celebrations, and most were said to be "complacent" of their safety because disastrous storms rarely passed through Mindanao. ${ }^{1}$ Unfortunately, the aftermath was reminiscent of the Ormoc City Tragedy $^{2}: 1,268$ residents were killed from either the flash floods or the landslides and mudslides that followed soon after. The catastrophe was so immense that funeral parlors in Cagayan De Oro failed to keep up with the tremendous demand for their services. Then-Iligan City Mayor, Lawrence Cruz, told local news channel GMA television that "[i]t's the worst flood in the history of our city" (Corrales et al.). Two years later, TS Yolanda claimed more lives in the Visayas region $(6,300$ lives as of count) and virtually flattened the landscape of Samar and Leyte. It is the deadliest Philippine typhoon ever recorded and the journey to recovery for the hardest hit regions is far from over.

Death and disaster can seem insurmountable in their after effects, but Filipinos, for better or worse, have been branded as "resilient." After TS Sendong, Cagayan De Oro and Iligan have promoted natural farming to rehabilitate the 650 farming households and 449 hectares of farm lands that were affected by the storm. Aside from this, hard-hit schools promoted "Dynamic Learning" wherein affected and traumatized students are given a series of psycho-social sessions to cope with their experiences of the flood, and to channel these into a renewed fervor for learning. A book entitled Bul-og: Streams of Learning from Sendong, was also launched in December 2012 by the Office of Civil Defense-10 to commemorate TS Sendong and the lives lost due to it, and to also advance the knowledge of the changes brought about by the disaster. Surviving residents from most of these disasters usually return to their houses and recover whatever is left of their belongings. For Filipinos, survival clearly precedes disaster; however, following each storm signal or rainfall warning, the yearly damage to infrastructure and agriculture, as well as the constant death tolls, make us wonder if we have really done enough to avert disasters like these. 
Why do these disasters persist in our country? Charlie Samuya Veric puts it this way: we Filipinos "know catastrophe the way we know the many names for rice" (2). Yet, as copious as these disasters are in our history, there is a sparse amount of literary work to heed its theme and even a sparser amount of framework theorizing about them. Paz Verdades Santos, in "Storm Signals: Climate Change in Bikol Poems," mulls over why there is a seeming lack of a creative or critical response to natural disasters in Philippine literature (67). She also recounts Oxford University's Environmental Change Institute conference wherein scientists and writers alike discussed how the cooperation of art and science could help in addressing the issues of climate change. This dialogue opens the doors to the necessity of art particularly literature - in contributing to the topic of environmental crises. Is it possible, that literature can also promote survival through the exploration of death and disaster in poetry?

The goal of this paper is to discover the wisdom in the Filipino ecopoetry of disaster, death, and survival in order to bring about sustainable ideas and change in society. To do this, I will explore the different versions of disaster, death, and survival in Philippine literature: the more popular poems of natural catastrophe and Rotor's scientific version of disaster to analyze what kind of ecologically literate tendency these kinds of poems show, and how they can be of benefit to sustainability. Here, I will introduce the concept of "dismantling" selected ecopoems to discover and sum up the knowledge gained from the literature of disaster, death, and survival and its impact on the ecological literacy of our society. This process draws on dark ecology, ambient poetics, and ecomimesis to construct its framework. Dark ecology will surface the "scars of history" in poetry, which will in turn become the ambience that surrounds in "ambient poetics." Then, as ambience surrounds us with disaster, ecomimesis will link the inner feelings of human beings with the place that is dismantled to create a space for survival. This concept will support the idea of sustainability in ecocriticism by linking our relationship with natural disasters as an outside-inside poetics and by providing a space for the flourishing of its ideas through this relationship. To further discuss this theory, I will ecocritique five poems: three from poet and biologist Dr. Abercio V. Rotor's Don't Cut the Trees, Don't!: "Talisay, Tree of Death and Rebirth" (89), "Dying Pond" (15), "Ad Infinitum to Doom" (101). Another will be Merlie Alunan's "Letter to Amina, Who Must Surely be Among Angels." I have decided to use the terminology "literature of disaster, death, and survival" for two main reasons: first, this terminology encompasses the experience of all species when disaster strikes; and second, the Filipino's experience with disaster and death is constantly a precedent to survival in the end. 


\section{DISASTER AND DEATH IN ECOPOETRY}

Philippine literature is abundant in poems of natural disaster. Common ones are of storms and flash floods, as shown by Merlie Alunan's famous "Letter to Amina, Who Must Surely Be Among Angels" which is a poignant work about a loved one's death during the Ormoc City tragedy. Another region often characterized by its affinity with storms and disasters is Bicol, since it is the usual entry point of tropical storms into the Philippine Area of Responsibility (PAR). Because of this, Bikol writers often speak of disasters and survival in their literature. An example is Abdon Balde Jr.s "White Storm" or "Bagyong Ugis" ${ }^{3}$ which describes a storm strong enough to make the rain appear like powder and white as milk; this poem is also dedicated to the victims of Bagyong Reming back in 2006. Other Bikolnon who have written about their experiences with disastrous storms are Merlinda Bobis (in Ang Lipad ay Awit sa Apat na Hangin) and Marnie L. Kilates (with the collection, Mostly in Monsoon Weather). Santos explores Bikolano poetry using ecocriticism in her journal article, "Storm Signals: Climate Change on Bikol Poems." There are also some occasional poems that have dealt with the extreme changes in temperature like Miguel Balboa D’Mendoza's "Another Sizzling Summer” and Gil S. Beltran's "La Niña," which were both published in Ani: The Philippine Literary Yearbook, an issue on the literature of disaster and survival. It is in this same anthology that earthquakes are explored in Ayn Frances dela Cruz's "Prayer." Priscilla Supnet Macansantos in "Close Calls" writes about landslides as she recounts her experience of traveling down Marcos Highway while remembering the devastation of the mudslide in La Trinidad, Benguet. Rocket Kapre Books, Inc., an independent publisher, has collated an anthology of short stories and poems entitled Ruin $\mathcal{E}$ Resolve to collect funds for the Philippine National Red Cross (PNRC) in the wake of the Ondoy and Pepeng tragedies. It was then re-released as a free e-book after TS Sendong. More recently, local and international Filipino poets have gathered their own works to come up with Verses Typhoon Yolanda: A Storm of Filipino Poets (edited by Eileen R. Tabios and published by Meritage Press, Inc.) as a fundraising anthology for the victims and survivors of the said super typhoon. Other anthologies and publications for the same cause are soon to follow within this year.

As shown by the literary works previously mentioned, when we discuss disaster, death, and survival in literature, we commonly associate it with the following natural disasters: floods, landslides, mudslides, earthquakes, tsunamis, heat waves, etc. Yet, there is more to disasters than those which directly affect us human beings. Catastrophes affect all species: when a place is flooded, humans swim alongside other animals to safety, and the storm's strong winds uproot centuries-old trees. Aside from this, there are also man-made disasters (also commonly termed as anthropogenic disasters) which are direct results of human will and intent. These may include technological, sociological, and transportation hazards like nuclear 
bombs, mass hysteria, traffic accidents, and the like. These disasters, no matter which kind, affect all species. The most common and devastating impact of these is death.

Death, as with disasters, also has different kinds in forensic entomology. Death is when the body experiences a physical shut down and different organs cease to work ("An Overview of Forensic Etymology"). This physical shut down can be through natural or accidental means. A disaster is a phenomenon that happens as a natural process of life, and when it happens to any place or species, survival follows. Deaths from disasters are accidental deaths that were not foreseen, preplanned, or intentional. These are alarming for they are signals that something went wrong before, during, and after natural occurrences. Now, these ideas bring up the following queries: How is the literature of disaster, death and survival of benefit to the promotion of sustainability? More importantly, in discovering its benefits to sustainability, is it possible for poetry to help prevent catastrophes in the future?

\section{THE PROCESS OF DISMANTLING}

Disasters and deaths are negative experiences. Paul Saunders describes these themes of literature as "the scars of history into artistic form, [which] works to tear down the ideological scaffolding that holds the modern experience of nature together" (55). These eco-writings become more historical than existential for they serve as "recorders" of the disastrous events and the subsequent personal encounters with these. However, if depicted as purely negative experiences, Robert Pogue Harrison sees that this collective theme can be dangerous "abortive documents of despair, refusing any positive ecological content that might underlie their seemingly grim reductions" (qtd. in Saunders 55). To depict these disasters only as lamentations will rebut their ecological value. Pure negation will overwhelm the "witness accounts" of the disasters by discussing only abstract feelings instead of witnessed reality, consequently isolating the literature's intention from its readers.

Timothy Morton describes disasters as "Dark Ecology" - ecological literature that sees nature in pain and giving pain to force us to make a critical choice about our actions, rather than serve as only abortive documents of despair. Here, the interconnectedness of ecological thought continues to the point of suicide: we make a critical choice to stay with our dying world. He says that:

Now is a time for grief to persist, to ring throughout the world. Modern culture has not yet known what to do with grief. Environmentalisms have both stoked and assuaged the crushing feelings that come from a sense of total catastrophe, whether from nuclear 
bombs and radiation, or events such as climate change and mass extinction ... If we get rid of the grief too fast, we eject the very nature we are trying to save. (Morton 185)

There are significant reasons why natural catastrophes compel us to write about our grief all too well: first, to document what has happened; second, for catharsis; and third, as Morton reiterates, for self-preservation. If we forget the moment during we are ecologically conscious of the reasons why this natural disaster happened to us, then we forget why we need to continue to write about disasters or create ecocritiques like this in the first place. Yet, as we write about our grief and survival, we also find ways for the survival of our dying world. One of the more tangible ways of developing a way of surviving ecologically is through the framework of sustainability. Sustainability's basic principle is to create and maintain the peaceful harmony of existing human and natural communities, permitting all kinds of ecosystems (natural, industrial, commercial) to co-exist for the present and future generations. Hence, it is possible to use our "scars of history" as the tools to push us toward writing about disasters and subsequently, discovering sustainable ideas so that these traumatic experiences do not happen again. If this is the case, how can poetry be an effective means of expressing the kind of grief that ecocriticism entails for tangible sustainable ideas?

The answer may lie in Morton's "ambient poetics." Ambience is an inside-out form of a rhetoric of "situatedness," which according to David Simpson, is linked to the urgency of impending and "threateningly nondiscriminatory" ecological peril (qtd. in Morton 33). It is pervasive since "no one now thinks himself immune to radical threat." In ambience poetics, a "circumambient or surrounding" world is shown as intangible to conjure a concrete image of a place or experience. Furthermore, Morton says:

Ambience, that which surrounds on both sides, can refer to the margins of a page, the silence before and after music, the frame and walls around a picture, the decorative spaces of a building (pararegon), including niches for sculpture - a word that was later taken up in ecological language. (34)

It is the ambience of poetry where we find the atmosphere of grief and disaster. This ambience is designed to surround us with these "scars of history" - the images of disaster and death - to disarm us, to overwhelm our senses, to cement our grief in poetry so that we do not forget. Morton explains that ambient poetics is most effective in a "negative quantity" - the absence of something "there," which evokes an impression of sheer space (46). Negative quantity is mostly associated with silence. It is in the absence of sound or words that a space is created to uplift the grief into a memorable moment. For example, forty days after Sendong occurred in Mindanao, the victims' families commemorated the tragedy by observing 
seventeen minutes of silence all throughout Cagayan De Oro. How can this negative quantity be manifested in ecopoetry? The visual may be through its punctuation: the ellipses signify suggestive transportation and a pause that promotes staying-inplace endowed within its own intensity, while the parenthesis or syncope extends the phrase or sentence within it into a plateau or suspension: as Wordsworth says, a "spot of time" (qtd. in Morton 46-47). The caesura ${ }^{4}$ and the enjambment ${ }^{5}$ are also negative quantities which denote pauses of sheer spaces for reflection. Even the blank space of the page may be seen as an "essential quiet" that articulates feeling (Howe 20o). Thus, the eco-poet, through this ambiance, intentionally fills the imagery with disaster and death to unintentionally bring us to a moment of silence, absence, where the space is created to clear all the grief away (catharsis) for a moment of commemoration and reflection. Morton's ecomimesis brings the outside and inside experience together to form that space: "When ecomimesis renders an environment, it is implicitly saying: 'This environment is real, do not think that there is an aesthetic framework here"' (35). Ecopoetry becomes a "strong magical form, a compelling illusion rather than a simple copy" (54) for the emotions it evokes from the reader are real. The dismantling experienced outside through the poetry and inside through the sharing of grief with the persona are genuine. Literally, the ambience of disaster dismantles us both inside and outside to create this silence, this "space." It is similar to the occurrence of disasters - whether flash floods, land or mudslides, earthquakes, volcanic eruptions, etc. - which surrounds us, traps us, envelops us, and destroys a part of us as death settles in. Catastrophe too, eventually brings us to a point of reflection - the exact moment when we look at the clearing brought on by the disaster - and we are left with nothing but to contemplate on what we are to do next. Eventually, the disaster or catastrophe that happens on the outside is brought into our feelings when realization or catharsis settles in. The survival part - whether it is physical or emotional - happens when the inside and outside disasters are brought together to give a new significance to the clearing or space left behind, wherein the human being can utilize this space to move on from the disaster and start life once again.

Ecopoetry's dismantling of disasters has similarities with Holocaust literature and contemporary disaster poetry. Poets like Sylvia Plath, Jerome Rothenberg, Charles Reznikoff, and Gerard Stern all wrote to answer an "urgent need of revealing what had happened during the holocaust [to produce] a distinctive literary formtestimony" (Wang 118). Holocaust literature is written to provoke controversy by inducing repulsion and acclaim in equal measure (Boswell 1). Once these literary texts gain attention, their aim is to reflect on one primary question: "What does it mean to say I have survived?" Upon this reflection, poetry becomes testimony, a key mode which helps us construct the relationship with contemporary historical drama. Harriet Parmet further asserts that poetry written about or after facing disasters become "a moral obligation as commemorating, catharsis, atonement, 
history, and insistence on human sensitivities; as resistance to brutalization indifference, flight from consequences" (qtd. in Wang 116). Morally, writing about disasters is a way of expressing that you are doing something about it and that you are, ethically, addressing what had happened. Contemporary disaster poetry is a serious moral obligation; as new century brings with it more natural and man-made disasters, eco-writers are moving away from fantasy and are seriously considering their ecological consciousness upon writing poems. Through this, ecopoetry is a powerful "witness to history," which proves the most important function of disaster poetry in our society (Zhenzhao qtd. in Wang 119-120). To write about disasters is to acknowledge survival, conquer trauma, and provide a personal perspective to historical survival accounts.

Take Alunan's “Letter to Amina, Who Must Surely Be Among Angels." Here, the persona addresses a letter to a family member who perished in the Ormoc City Tragedy, recounting the ordeal of volcanic eruptions from nearby Pampanga's Mt. Pinatubo, earthquakes, and the deadly flash floods that were then "drowning our city in an hour's rampage." What is most heartbreaking about the poem is the persona's personal account of having to go to the same hill that Amina herself used to frequent to search through "the leavings of water, the mud, the rubble, the debris, and the countless bodies littering the streets" (30-31) for her family. There, the persona finds the overwhelming scenery of death.

Alunan bombards us with violent imagery of the Ormoc City tragedy, using the words "war," "famine," "bursting," "shaking," "broke," "drowning." She does this excessively, and the lines of the poem read as if they are without any pauses - each stanza consists of mostly one period and countless other commas to offer a moment to breathe but not to stop. However, the most striking feature of Alunan's poem is the use of dashes:

\footnotetext{
I remember your women's beauty fading,

And this, what's left for a daughter to touch -

Your namestone mute among the grass green singing,

Your name I raise to the wind like a prayer.

If you hear it whispering in the lift and fall

Of angel wings, please send word somehow - (39-44)
}

Here, the dashes invoke an ambience of incompletion, a wanting, for the persona. The line, "And this, what's left for a daughter to touch -" (40) is very sharp, for the dash here pauses the bombardment of grief to leave us with a feeling of longing in the exact same way that the persona reflects on having lost the ability to physically touch Amina. This is the negative quantity of the process of dismantling. Unlike the ellipses which when used in the line would have denoted a pause that leaves 
much room for reflection, the dashes are abrupt - as abrupt as the death of the persona's mother - to evoke the intensity of yearning. The dash functions as an intense stoppage that is as sharp as the grief of the persona and which forces the loss on us: the grief is dismantled inside of us to show that what is on the outside (the namestone to commemorate the Ormoc City tragedy victims) will never be enough to avert the pain. The line, "please send word somehow-" functions in the same way, where there is a silence that follows the dash as the poem jumps to another stanza, and a shift in the persona's pleading:

\author{
Have they given you back your voice? \\ I'd like to know - lost among the angels \\ What can a woman sing? \\ And what do you remember? (45-48)
}

In the end, the poem becomes more insisting and desperate. The dashes and the shifting perspectives which follow after each show the irrationality of grief; whereas the negative quantity, the silence, that occurs in between the dash and the shifting perspective leave us a space to reflect on the poem's grief and be dismantled by the catharsis we may experience by reading it. The outside grief of the poem is brought to our insides for its ambience appeals to our familial relationships, to our own "scars of history." Ultimately, after disaster poems like Alunan's, we are left with a silent clearing in ourselves for us to come to terms with our own, now shared, grief. This idea is explicated furthermore by Morton when he says that "[e]cological politics must constantly and ruthlessly reframe our view of the ecological: what was 'outside' yesterday will be 'inside' today. We identify with the monstrous thing" (195). How does the ecopoem's ambiance now bring forth sustainability? As literatures of disaster force dismantling, there is learning in the space the dismantling leaves behind. In "Letter to Amina," it is in the breathing room of the dashes and the shifting perspectives after the ramming of violent imagery: the moment when the poem's visual and aural aspects both pause to honor the negative quantity of the poem. As we are conscious of the grief dismantling us, we are also ecologically conscious of why this has happened in the first place. We understand that we share the same grief with the persona because we have the same "scars of history;" we are ecologically conscious that this has been brought about by a natural disaster, that by all means, it is also a man-made disaster for it could have been avoided through conscious efforts from public and private citizens. When we reach the pinnacle of the persona's grief in the line, "have they given you back your voice? I'd like to know -", the momentary stoppage creates a space where together with the persona, we realize that Amina is never coming back ("lost among the angels"). These spaces are the spaces of sustainability. It is in the ambience of silence - after the flood dissipates in Ormoc, after the storm has passed in Ondoy, after the landslides in La Trinidad, during the rehabilitation in Tacloban - that personal and national 
paradigms are reassessed and reevaluated from why is this happening to me? To what did I do to deserve this? To finally how can this be prevented in the future? It is in this space that survival is present. After the dismantling, the clearing (the wipe-out) enables us to think openly of what happened and what can happen next if situations do not change. It is the same with real life situations, wherein after particularly devastating natural disasters, the government and its citizens come together to brainstorm on relief operations, assessment of damages, and means of prevention. Hence, sustainable ideas may be created and realized through these efforts.

It is possible to use poems like Alunan's and so many others' as concrete representations of the pain and aftermath of natural disasters. In science, it can be a "time capsule" or a historical witness account of firsthand experiences with the disaster which can clarify questions regarding the incidents. In literature, it can inspire critical discourses on the nature of catastrophe and survival; the mere discussion of these "scars of history" is enough to bond the grief toward our ecological consciousness, as a reminder and warning all at the same time. In education, these can be used to teach about the effects of disasters and can be used as motivations for ecological, historical, and literary instructions.

Not all poems are as grief-stricken as Alunan's though. Rotor's poems are mellower and more ecological. They rarely speak of an infamous catastrophe in the country. Yet, in ecopoetry, Rotor's own interpretation of a disaster is a necessity for it talks about the smaller natural disasters occurring daily in our environment which most Filipino eco-poets do not write about. His preemptive poetic exploration of smaller scale disasters in our environment may be where efficient sustainable ideas can come forth.

Rotor's “The Dying Pond” is a good example of his unconventional literature of disaster. In the poem, an old pond is overtaken by a murky swamp as it "dies" in peace. Once the swamp completely dries up, grassland comes from the old pond's location and is frequented by animals. It ends with a woodland rising from the former pond and hiding its traces of death in dense greenery.

From a reader or a critic's point-of-view, poems like Rotor's hardly seem "disastrous." Yet, as Theodor Adorno mentions in his essay, "Progress," we ourselves must become "aware of our own indigenousness to nature" (qtd. in Morton 196). As was established beforehand, we are part of nature and whether we like it or not, anything that happens within nature directly affects us human beings. The idea of dark ecology is to merge the outside (nature) with our inside (feelings) to see ourselves as part of this "monstrous thing," rather than to merge our inside (feelings) with the outside (nature) to use nature as a framing device for our feelings. As a part 
of nature, we come to terms with the reality that changes within our environment can eventually be disastrous and tragic for all species. In the unification of what's outside and inside of us, we appreciate the death of a pond as a natural disaster, too - not as emotional as the Ondoy or Sendong tragedy, but a tragedy nonetheless: one that ends with survival and shows the evolution of life in an ecosystem.

What kind of tragedy is "The Dying Pond" and how can this be a space for sustainable ideas? The answer may be discovered in ecocritiquing the poem with the concept of dismantling.

The page of the poem appears with Rotor's painting of a "Pond in Summer." The painting illustrates a healthy, thriving ecosystem - a reminder of an ideal environment before the reading of the poem. It is a proficient precursor to the first stanza, which goes directly to the descriptions of death: "dreaded fate," "dying pond," "a swamp in its place," "dying in peace and grace." These phrases give the imagery of a murky, brown, uninhabitable place - a sharp contrast to what was once a healthy, thriving ecosystem. However, as Rotor dismantles the idyll concept of a pond (and the picture that he includes in the page), he ends the first stanza with a line that shifts the ambience of death into a stoppage. It is here that we find the negative quantity of the poem:

\section{As on a dying pond, a swamp in its place \\ Grows, dying in peace and grace. (3-4)}

In the line-break "a swamp in its place," the reader still has the constant ambience of death present, but in the following enjambment, there is a blunt change in tone that accompanies the words. It is in this shift, this negative quantity, that the reader is treated to a pause - a chance for a space, a clearing, as a preparation for the survival that is about to happen. The process of dismantling, though short and clipped in the poem, leads to the moment that something beautiful and familiar is dismantled into a dirty, muddy place. It is all that is left after the death of a pond; however, the shift in tone and imagery is a space for the reader to start contemplating the survival that is present in the next few lines. How does survival come to an already-dead pond? The next stanza answers that:

And the watery grave dries into grassland

Where roam the hoofs and paws in band;

And the winged sweep the air, retreating

On the trees nearby, and advancing. (5-8) 
The swamp becomes the grassland, transforming it to a haven for the species who are pilfering for food. The species are diverse - hoofed, with paws, or flying above the ground from tree to tree. The activity that these species bring with them as they curiously seek out the grassland is part of the natural healing process of nature: they are aides in pollination. The last stanza clarifies this:

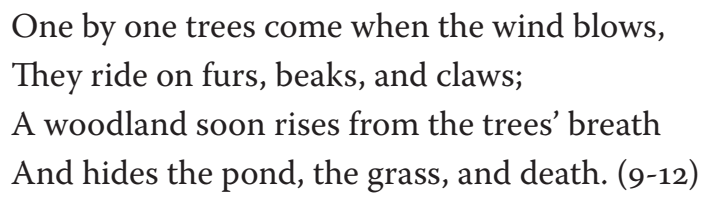

The seeds of the trees and plants are brought by the wind, "furs, beaks, and claws" to the grassland. Eventually, they are all implanted into the soil (where the dying pond used to be) and grow into a woodland. The lush greenery brought about by the new trees and plants hides the traces of the dying pond, and life begins anew. "The Dying Pond" is a tragedy of a natural death, but one that persists by allowing a space for another ecosystem to grow.

This is one of the many ways nature survives on its own: it can fix what was dismantled. The dismantling in the poem attempts to show the readers that nature can create life out of tragedy. This idea from the outside can merge with our feelings from the inside about our own plight for survival in tragic circumstances, for we are parts of nature. The space found in the enjambment in the first stanza demonstrates that survival after tragedy is inevitable - we only need to let everything run its course.

The ideas of sustainability come from further analysis of the poem: if the poem shows how nature can heal itself through pollination, what happens if the process of survival is interrupted? What if there are no "hoofs," "paws," "beaks" to bring the seeds of other trees? Or what if there are no trees at all surrounding the dying pond? Will it still be the woodland in the poem's ending? These are interesting queries that can be used for both scientific and educational purposes. These can spark ideas of sustainability which will be of benefit to our overall knowledge about species, place, and nature.

The same theme resonates in Rotor's "Talisay, Tree of Death and Rebirth." The ecopoem's persona tells the death of a Talisay (or the more commonly known umbrella tree) in its final process of decay. As its leaves fall one by one, the persona praises the tree for sacrificing its "crown" for the survival of its "tenants." What ideas of sustainability can this poem about the Talisay offer? 
In the first stanza, the persona is patiently looking at the Talisay tree, waiting for a "gust of wind to shake you up and make you a skeleton in the blue sky." It is obvious that the tree is in an advanced state of deterioration and even just a "gust" of wind will make its leaves wither away from its "skeleton." While the persona views the outside (the dying Talisay), inside he merges his feelings with it by realizing that their nakedness will be the same when he grows old. This is a premature outsideinside merge, and we are not given the space up until the middle of the second stanza, where the ambience and the bombardment of images of death begin:

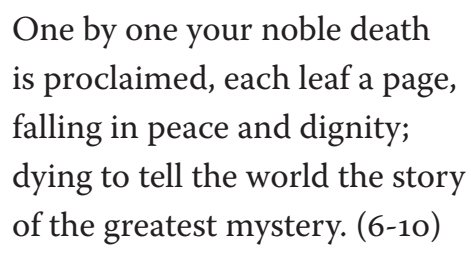

The imagery is of a slow, precise demise: the leaves precipitate the Talisay's end as they fall one at a time. The deliberate slowness of the falling leaves allows us a pause - not a stoppage yet - to reflect on what the leaves are "dying to tell the world." What is the story of the Talisay tree and why is its death of great importance to the persona?

The answer lies in the final stanza, where the tree "loses its crown and die a little in order to resurrect" its tenants. What does this mean? The Talisay tree is a natural antiseptic. Since it usually grows near rivers or lakes, its dead and dried leaves fall into the river and emit a strong brown dye. This is poison which is used as a natural defense against parasites. When in water, it becomes an antibacterial for the water's acid level - it absorbs harmful chemicals and helps soothe the fishes' environment. Many have observed that fishes in rivers surrounded by Talisay trees become healthier and more vibrant in color and form. Not only that, but the Talisay's bark and fruit also have healing properties for they have been known to treat dysentery, colic in children, and hypertension. With this background knowledge in hand, reading the poem's final stanza becomes clearer:

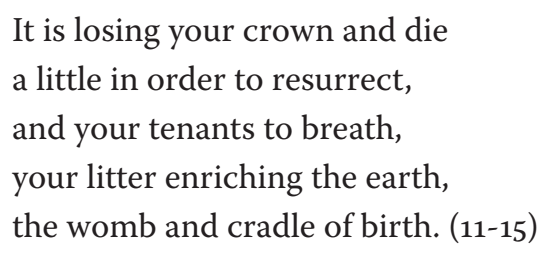

The negative quantity occurs in the irony when the persona mentions "die a little in order to resurrect" wherein we are offered a space to contemplate about what lives when the Talisay dies. It is in this space that we are allowed to think 
about the subsequent lines that mention "tenants to breath [sic]" and the tree's "litter enriching the earth." With proper schema of the tree and its properties, we understand that the "tenants" are the fish who are given a healthier environment because of the Talisay's death. Talisay, as it dies, literally "enriches" the earth with the remnants of its leaves and bark. The last line which says, "the womb and cradle of birth" indicate that life begins again because of the tree's death, another testament to nature's unique way of surviving.

"Talisay, Tree of Death and Rebirth" is a piece that is not only an example of dismantling in its imagery and message (the dying tree being dismantled with its leaves falling one-by-one and ironic survival), but it also implies educational information about the properties and benefits of the Talisay tree. Readers learn that in its death, the Talisay's leaves and bark become natural antiseptics to other species which live near it. This ultimately enables these other species to live healthier lives. Sustainable ideas already stem from that; however, what we also learn from the poem is that in disaster poetry, nature's process is give-and-take: one species gives, the others take. It is a natural process recognized in ecology and is called mutualism. ${ }^{6}$ If applied in consumerist society, mutualism will benefit both natural environment and human beings for it will allow humans to gain resources without depleting the supply. At the same time, human beings must also find sustainable ideas to maintain the resources which, in turn, benefit the natural environment affected in the process. If we learn from this ecological mutualism and apply it in our consumerist and capitalist decisions, then most probably there could have been lesser damages and deaths when it comes to surviving disasters in the country. One of the ways to introduce ecological mutualism to values formation is through education. The principle needs to be integrated from a company's start up, and education can accomplish this by including sustainable ideas and poems like "Talisay, Tree of Death and Rebirth" in its pedagogy, to teach everyone the giveand-take relationship that can be practiced. In the end, we can survive because we sustain all species' survival in the biosphere.

Rotor's next poem in this ecocritique summarizes the interconnectedness of these environmental deaths with our own mortality. "Ad Infinitum to Doom," literally means "again and again in the same way to doom." It is a dark ecological poem, one which uses association by pinpointing that when a species of the ecosystem dies, another different species also dies. In the end, Rotor demonstrates his scientific knowledge by linking the death of a tree to the death of a whole town. Here is the poem in its entirety:

When a tree dies, a rivulet dies;

When a rivulet dies, a stream dies;

When a stream dies, a river dies;

Kritika Kultura 25 (2015): -045

(C) Ateneo de Manila University

<http://kritikakultura.ateneo.net> 
When a river dies, a lake dies;

When a lake dies, a valley dies;

When a valley dies, a town dies

Ad infinitum to final doom. (101)

There is no direct scientific correlation with the death of a tree to the death of a town, yet what Rotor means to discuss is the scientific fact that a death of any kind of species in an environment may be a prelude to the deterioration of the ecosystem. Simply put, loss of any species is an imbalance in the ecosystem; thus, the imbalance may precede a disaster.

In the poem, the first sign of the deterioration is the dying tree. Then, the water sources all dry up - the rivulet, the stream, the river, the lake - which is a stark indication of loss of lives among the living species. As desertification settles in, the valley and town die simultaneously - obviously together with their inhabitants of all species. Rotor ends it with the line, "Ad infinitum to final doom," which indicates that the occurrences described in the poem are not unique. This situation can definitely happen again until our ecosystem has died.

Where is the dismantling in this poem? First, it is in the caesura (the comma) in between each of the lines. There is a pause which also mirrors the stoppage of the subject's mortality; here, we are roused to ask "why is there death?" or "what happens next after death?" Then, the next space offers a space of reflection through the semi-colons. Semi-colons are used in poetry to indicate two independent ideas that are related to each other. Rather than be bombarded with the ambience of disaster and death, the poem gives the reader a space to breathe in the semi-colons. It is in these marks that a clearing is prepared for the final delivery of the last line. It is also in these marks that one is able to contemplate on the link between the previous death and the death in the next line. One may ask, what does this mean for us if these deaths occur in our environment? Can these deaths be the warning signs for our final doom? These thoughts themselves provide the space for the dismantling since they already tear down the idyll environment that people assume to be sustained forever without any maintenance from human beings. Aside from this, they also warn of an impending doom if sustainability is not adapted in a community.

It is easy to locate ideas of sustainability for survival in poems like "Ad Infinitum to Doom." Since it already appeals to the reader's fear, a poem such as this may educate on what the indicative signs of a dying environment are and how they can be prevented starting with a single "tree." For science, a poem like this can be representative of the extinction of species or desertification. In literature, poems like these serve as reminders of what may happen if we do not do our own part 
in sustaining our environment. Elizabeth Ammons says that "one of the ways environmental injustice perpetuates itself is by remaining invisible to those who benefit from the targeting of others" (106). In Rotor's "Ad Infinitum to Doom," that which is targeted is visible to the reader - from the single tree to the bigger benefactor that is the town and its inhabitants. The sustainable thoughts and ideas which are surfaced from the ecopoem may be tangible ways of preemptive measures for greater chances of survival after future disasters.

\section{SURVIVAL: THE PROCESS OF DISMANTLING FOR ECOLOGICAL LITERACY}

The concept of dismantling goes beyond this ecocritique - it attempts to answer this query, which I raised at the beginning of this article: is it possible for ecopoetry to prevent the catastrophes that cause these disasters?

Directly, no. Poetry cannot be the physical embodiment of disaster-prevention measures being undertaken by the governments and their societies; simply put, poetry cannot explicitly talk about what to do and what not to do to prevent or prepare for natural catastrophes. It cannot give a list of what went wrong and what can go wrong if we do not become ecologically conscious. In the discussion of disasters, deaths, and survival, the role of poetry is simple yet imperative: poetry can be a vehicle to express the emotions of individuals upon facing natural catastrophes and surviving them; poetry can become a record of experiences and imply that these can happen again if we do not proactively change our systems and beliefs; poetry can be a stern reminder of what went wrong and what could still go wrong if we do not become ecologically conscious. Ecopoetry, in particular, can compel us to discuss, rethink, and reshape our paradigms from preparing for disasters and deaths to preparing preemptive measures for the assurance of survival.

Furthermore, poetry has become a "time capsule" of certain tragedies. Ecopoetry is the poetry of witness, one that is far more accurate than memory ever will be after a few years of what happened and why it happened. Testimony in ecopoetry offers an outlet for survivors to express their experiences and survival with a scream and cry, or it is an effective way of expression for the artists who are absent from the scenes of the catastrophe (Wang 118). Poetry is a vestibule of grief; it is a dismantling device that shows us the painful extent of our grief and the reason why we do not want to experience that again. It attempts to make "sense" of a disaster and creates a space for ecological consciousness. It allows us to be aware of smaller scale disasters in our environment to realize that these contribute to the bigger catastrophes we are experiencing. It lets us learn from nature and its ecological mutualism, so that when it is our time to "give our life," we do so with acceptance because we understand that it is but a natural process of life. It makes sure we 
never forget key ideas from our survival so that we continue on with our lives more knowledgeable about ourselves and the environment than before.

Aside from these, poetry can also be a means to heal the trauma inflicted upon the survivors of a disaster. There have already been studies which show that poetry (or writing in general) aids in therapy sessions after a clinical illness. Physicians and/or psychiatrists use poetry to empower their patients to express themselves, to let them find their "voice" in their struggle, or to realize that they are not alone in their illnesses and there are others who suffer the same condition. Robert Carroll, a psychiatrist who has explored the use of writing in treating cancer survivors, states that:

Our voices are saturated with who we are, embodied in the rhythms, tonal variations, associations, images and other somato-sensory metaphors in addition to the content meaning of the words. Our voices are embodiments of ourselves, whether written or spoken. It is in times of extremity that we long to find words or hear another human voice letting us know we are not alone. (164)

Not only can poetry help us remember and commemorate disasters and deaths, but it can also heal the trauma through the communal feeling of survival. The oral and aural aspects of poetry, when brought together, support the concept of dismantling through the cathartic experience initiated by the writing, reading, and speaking processes. The trauma is dismantled within the survivor to make way for sustaining survival. For those of us who have not experienced these disasters and deaths, we are drawn into the disturbance and share the feeling with those who have been through it, so that we are also dismantled inside with the realization that these events happen and they can happen to us, too. After dismantling, we contemplate on how we can prevent these from happening again through the conceptualization of sustainability in our culture and environment.

There are so many ways that poetry can prevent catastrophes when utilized in ecological discourse. Education, science, and literature together are a powerful tool and these may be established through ecological literacy.7 Poetry like the ones in this paper can be used to educate about disasters - their causes and the aftermath. Science can use poetry as witness accounts to accurately detail what had happened during a certain tragedy for future prevention. In literature, we find a voice in poetry that allows us to come to terms with our grief; this way, we ourselves experience our own dismantling. It makes the invisible visible through the ambience and spaces it dismantles and creates within us.

Poetry inspires all - writers, teachers, scientists - to create ideas of sustainability for to prevent the bigger disasters, we also need to prevent the smaller scale ones to 
ensure that all species can anticipate and outlast the next Sendong, Ondoy, Maring, or Yolanda. Perhaps in the remembrance and reflection of literature, we have found another way to rebuild what was once dismantled so that we can sustain the earth and survive. 


\section{Notes}

1. Further information about the Sendong flash flood was obtained from an article by Cong Corrales et al. from Interaksyon.com.

2. Tropical Storm "Thelma" ravaged Ormoc City in 1991 and overwhelmed the Anilao-Malbasag Watershed, which unloaded water through the also denuded forests of Ormoc City. Within one hour, the city was swept in the flash flood, displacing 3,00o homes and damaging 11,00o others. In Ormoc alone, 4,922 were killed and around 1,80o to 3,00o were left missing.

3. "Bagyo" or "Bagyong" in English is "storm."

4. This is the punctuation mark which is found within the line of a poem.

5. An idea or a phrase is paused and carried over to the next line of the poem.

6. Mutualism in ecology is a kind of facilitation, where in species interact with another and benefit from each other (Stilling 219).

7. Ecological literacy is unifying the writer's literariness and ecological knowledge to produce a body of work which understands the local environment and educates readers of the human and nonhuman interrelationship within it to motivate ideas of creating sustainable communities here on earth. In my graduate thesis, I conceptualized this framework in an attempt to establish ecopoetry as a tool of literature in contributing to the current ecological discourse of sustainability. 


\section{Works Cited}

Alunan, Merlie M. "Letter to Amina, Who Must Surely be Among Angels." Review of Women's Studies 4.2 (1995): 36-37. Web. 20 Sept. 2013.

Ammons, Elizabeth. Brave New Words: How Literature Will Save the Planet. Iowa: University of Iowa Press, 2010. Print.

"An Overview of Forensic Entymology." Forensic Science. ForensicScience.org, n.d. Web. 8 Nov. 2013.

Boswell, Matthew. 'Black Phones:' Postmodern Poetics in the Holocaust Poetry of Sylvia Plath." Critical Survey 20.2 (2008): 53-68. Print.

Caroll, Robert. "Finding Words to Say It: The Healing Power of Poetry." Evidence-Based

Complementary and Alternative Medicine 2.2 (2005): 161-172. Print.

Corrales, Cong. et al. "Death toll in flash floods rises to 440; more fatalities expected in Cagayan de Oro, Iligan." InterAksyon.com, 17 Dec. 2011. Web. 19 Dec. 2013.

Ellis, Marie. "Human Decomposition: Study Maps Internal Bacteria." Medical News Today. n.p., 31 Oct. 2013. Web. 8 Nov. 2013.

Franklin, Jerry, et al. "Tree Death as an Ecological Process." Bioscience 37.8 (1987): 550556. Print.

Morton, Timothy. Ecology Without Nature. Massachusetts: Harvard UP, 2007. Print.

Rotor, Abercio V. Don't Cut the Trees, Don't! Manila: University of Santo Tomas Publishing House, 2010. Print.

Santos, Paz Verdades. "Uran, Uran, Tagantan: Mga Babala sa Pagbabago ng Klima sa Rawitdawit Bikol / Storm Signals: Climate Change on Bikol Poems." Malay Literary Journal 24 (2011): 65-79. Print.

Saunders, Paul. "Samuel Beckett's Trilogy and the Ecology of Negation." Journal of Beckett Studies 20.1 (2011): 54-77. Print.

Stiling, Peter. Ecology: Global Insights and Investigations. New York: McGraw-Hill, 2012.

Veric, Charlie Samuya. "Storms from Paradise: Notes on Philippine Literatures and

Disasters." Archipelagic Feasts, Tropical Disasters. Pen Congress on the Literature of Survival. Cultural Center of the Philippines, Manila. 2 Dec 2011. Lecture.

Wang, Zhuo. "'Our Common Sufferings:' Reflections on the Ethical Dimensions of Contemporary Disaster Poetry." Journal of Cambridge Studies 4.4 (2009):114-126. Print. 